\title{
Soil texture and tree coverage influence on organic matter
}

\author{
D.E. BUSCHIAZZO, H.D. ESTELRICH, S.B. AIMAR, E. VIGLIZZO, AND F.J. BABINEC
}

Authors are Soil Scientist, Anguil Exp. Station, INTA, cc 11, 6326 Anguil, Argentina; Ecologist, Facultad de Agronomía, UNLPam, cc 300,6300 Santa Rosa, Argentina; Soil Scientist, Facultad de Agronomía, UNLPam, cc 300, 6300 Santa Rosa, Argentina; Ecologist, Anguil Exp. Station, INTA, cc 11, 6326 Anguil, Argentina, and Statistician, Anguil Exp. Station, INTA, cc 11, 6326 Anguil, Argentina. Corresponding author is D.E. Buschiazzo.

\section{Abstract}

Soil organic matter (OM) is an important factor for maintaining the productivity and the stability of the so-called Caldenal woodland ecosystem of central Argentina. Little is known about the influence of tree coverage and soil texture on OM accumulation in soils of the study region. The relationships between $\mathrm{OM}$ content, silt + clay content, and the percent of tree coverage were studied in a $25 \times 25$ m grid in 2 sites. Results showed that OM was lower $(\mathrm{P}<0.05)$ at Site I $(2.86 \%)$ than at Site II $(6.41 \%)$. The $0 \mathrm{M}$ was positively correlated with the percent of tree coverage in Site I $\left(O M=0.0156\right.$ trees cover $\left.+1.97, R^{2}=0.29, P<0.001\right)$, but not in Site II. Conversely, a positive correlation with silt + clay was observed in Site II $\left(\mathrm{OM}=0.17\right.$ silt + clay $-6.79, \mathrm{R}^{2}=0.41, \mathrm{P}$ $<0.05)$ but not in Site $\mathrm{I}$. A multiple regression analysis [OM = $16.64+0.71$ (silt + clay) + 0.04 (tree coverage), $n=78, R^{2}=0.55$, $\mathrm{P}<0.001]$ tended to confirm these results. Although they differed in their relative weight both silt + clay and tree coverage affect $0 \mathrm{M}$ accumulation at both sites. The larger influence of trees on $0 \mathrm{M}$ variability at Site I was attributed to the lower, but highly variable, tree coverage, and the stronger influence of silt + clay on $\mathrm{OM}$ variability at Site II can be attributed to the lower variability of tree coverage, and the higher variability of soil texture.

According to our results, (a) $41 \%$ of $O M$ variability is explained by silt + clay content when tree coverage is dense and uniform, and (b) a $29 \%$ of OM variability is explained by tree coverage when such coverage is sparse and heterogeneous. The influence of tree canopy on OM distribution could be explained by its effect on the temperature regime. The influence of soil texture on $\mathrm{OM}$ could be attributed to its effect on the water retention capacity of soils. While forest clearing increases the maximum temperature and the temperature amplitude of soils, erosion in cleared areas affects soil texture, and consequently, its water retention capacity. The deterioration of both temperature and soil water regimes deteriorates, in turn, the capacity of the soil to accumulate $\mathrm{OM}$.

Key Words: soil organic matter, grasslands

Soil organic matter (OM) is an important factor for improving the stability of semiarid environments, since it improves the soil resistance against wind and water erosion (Lal and Stewart 1990), the soil water holding capacity, and the nutrient availability for

This study was financed by Consejo Nacional de Investigaciones Científicas y Técnicas (CONICET) (PID 1993-1996), Anguil Exp. Station, INTA, and the Facultad de Agronomía, UNLPam, Argentina. Authors wish to thanks to Monica Mazzola and Edgardo Adema for field work.

Manuscript accepted 9 Feb. 2004

\section{Resumen}

La materia orgánica $(\mathrm{OM})$ es un factor importante para mantener la productividad y la estabilidad del ecosistema del bosque del Caldenal de la región central de Argentina. Poco se conoce acerca del efecto de la cobertura arbórea y la textura del suelo sobre la acumulación de $\mathrm{OM}$ en esta región. Las relaciones entre contenidos de OM, limo más arcilla y el porcentaje de cobertura arbórea se estudió en cuadrículas de 25 × $25 \mathrm{~m}$ en dos sitios del Caldenal. Los resultados mostraron que OM fue menor ( $\mathrm{P}<$ 0.05) en el Sitio I $(2.86 \%)$ que en el Sitio II (6.41\%). Los contenidos de $O M$ se correlacionaron positivamente con el porcentaje de cobertura arbórea en el Sitio I $(O M=0.0156$ cobertura arbórea $\left.+1.97, R^{2}=0.29, P<0.001\right)$, pero no en el Sitio II. Inversamente, se observó una correlación positiva con limo + arcilla en el Sitio II $\left(O M=0.17\right.$ limo + arcilla $-6.79, R^{2}=0.41, P$ $<0.05$ ) pero no en el Sitio I. Un análisis de regresión múltiple $[O M=-16.64+0.71$ (limo + arcilla) + 0.04 (cobertura arbórea), $\left.\mathbf{n}=78, \mathbf{R}^{2}=0.55, \mathrm{P}<0.001\right]$ confirmó estos resultados $\mathbf{y}$ demostró que las variables cobertura arbórea y limo + arcilla afectaron la acumulación de $\mathrm{OM}$ en ambos sitios pero con diferente peso relativo en cada uno. La mayor influencia de la cobertura arbórea en el Sitio I se atribuyó a la menor y más variable cobertura por parte de los árboles; mientras que la mayor influencia de limo + arcilla sobre OM en el Sitio II puede ser atribuido a la menor variabilidad de la cobertura arbórea y a la mayor variabilidad de la textura del suelo.

De acuerdo a nuestros resultados se puede concluir que (a) $41 \%$ de la variabilidad de $\mathrm{OM}$ es explicada por limo + arcilla cuando la cobertura arbórea es densa y uniforme, y (b) un $29 \%$ de la variabilidad de la OM es explicada por la cobertura arbórea cuando la misma es escasa y heterogénea. La influencia de la canopia arbórea sobre la distribución de $\mathrm{OM}$ puede ser explicada por su efecto sobre el régimen de temperatura. La influencia que la textura posee sobre la distribución de $O M$ se debería a su efecto sobre la capacidad de retención de agua del suelo.

Mientras que la tala del bosque incrementaría las temperaturas máximas y la amplitud térmica, la erosión de áreas deforestadas afectaría la textura del suelo $y$, consecuentemente, su capacidad de retención de agua. El deterioro de la temperatura y del régimen hídrico disminuiría, consecuentemente, la capacidad del suelo para acumular materia orgánica.

plants (Tisdale and Oades 1982, Rasmussen and Collins 1991, Gregorich et al. 1994). In the semiarid Pampas, Quiroga et al. (1999) observed an inverse relationship between OM and soil compaction. Díaz Zorita et al. (1999) found that a decrease in wheat yield of approximately $40 \mathrm{~kg} \mathrm{ha}^{-1}$ was associated with losses of $1 \mathrm{Mg} \mathrm{OM} \mathrm{ha}^{-1}$ 
The woodland Caldenal ecosystem of Argentina is composed by a spatial succession of woody and herbaceous strata. This succession of trees and grasses produces differences in soil temperature and soil water contents. López Cadenas (1990) and Powers (1990) demonstrated that in savannas, that the highest and lowest temperatures were not so extreme, and that the soil water content was higher below the trees canopy than outside the canopy. In the Chaco forest of Northern Argentina, Mazzarino et al. (1991) found that mineralization of soil organic matter was lower below larger tree coverage, indicating that a lower OM content can be expected in such areas. Random observations recorded in the Caldenal area, also demonstrated that the air temperature and the soil water content are less variable under the tree canopy than in open areas (Llorens and Frank 1999).

Mordelet and Menaut (1995) found in an humid savanna of Africa that beneath tree clumps, soil water content dynamics was slightly lower during the grasses growing season.

The general effect of climatic conditions on the OM accumulation rate has been established by different authors. Burke et al. (1989) found that OM content increased with increasing precipitation and decreased with increasing temperature. Similar results were found by Alvarez and Lavado (1998) for Mollisols in the humid and subhumid Pampas of Argentina. In the semiarid Pampas of Argentina, Buschiazzo et al. (1991) demonstrated that a positive correlation between silt + clay and $\mathrm{OM}$ accumulation occurs in Haplustolls and Ustipsamments. This relationship is the consequence of the positive effect of silt and clay on the water holding capacity of the soils, and therefore on the amount of biomass incorporated into the soil.

Management of this ecosystem can lead to changes in the botanical composition of grasses. Higher grazing intensity has probably decreased the deposition rate of plant residues to the soil (Facelli et al. 1988) affecting the amount of $\mathrm{OM}$ in the soil (Llorens and Frank 1999).

It is still not known how tree coverage and soil texture affect the soil OM accumulation in the Caldenal ecosystem. Further knowledge on this effect will be of considerable importance for identifying future strategies of forest clearing and preventing soil degradation processes.

Considering previous evidence, 4 hypothesis were tested: 1) the OM content of soil increases as the tree coverage of land increases, 2) both tree coverage and

Table 1. Mean percentage values of predominant biophysical attributes of the $\mathbf{2}$ study sites in the Caldenal woodland.

\begin{tabular}{cccccc}
\hline \hline Site & $\begin{array}{c}\text { Management } \\
\text { history }\end{array}$ & $\begin{array}{c}\text { Total organic } \\
\text { matter }\end{array}$ & Tree-coverage & Silt+clay & $\begin{array}{c}\text { Water-holding } \\
\text { capacity }\end{array}$ \\
\hline I & $\begin{array}{l}\text { Systematic } \\
\text { Burning }\end{array}$ & $2.86 \mathrm{a} \mathrm{(18.02)}$ & $57.08 \mathrm{a} \mathrm{(31.20)} 72.80 \mathrm{a} \mathrm{(3.80)}$ & $25.50 \mathrm{a} \mathrm{(5.38)}$ \\
II & No burning & $6.41 \mathrm{~b}(24.70)$ & $70.40 \mathrm{~b}(18.50)$ & $78.50 \mathrm{~b}(6.00)$ & $27.60 \mathrm{~b}(7.00)$ \\
\hline
\end{tabular}

Different letters indicate significant differences between Sites for each variable $(P<0.05)$

Number in parenthesis is the standard deviation.

soil texture can explain a significant part of the OM variability, 3 ) the relative weight of tree coverage and soil texture on the OM content depends on land coverage density, and 4) another part of the statistical variability can be attributed to other factors (probably antropic) that were not studied.

The objective of this study was to analyze and interpret the $\mathrm{OM}$ accumulation in soils of the Caldenal woodland as a function of tree coverage and soil texture.

\section{Materials and Methods}

This study was carried out on 2 sites of the Caldenal woodland ecosystem (Fig. 1). Site I $\left(36^{\circ} 20^{\prime} \mathrm{S}\right.$ latitude, and $65^{\circ} 00^{\prime} \mathrm{W}$. longitude), and Site II $\left(36^{\circ} 30^{\prime} \mathrm{S}\right.$ latitude and $64^{\circ} 30^{\prime} \mathrm{W}$. longitude) were selected on the basis of different fire histories, tree canopy coverage, and soil texture. At both

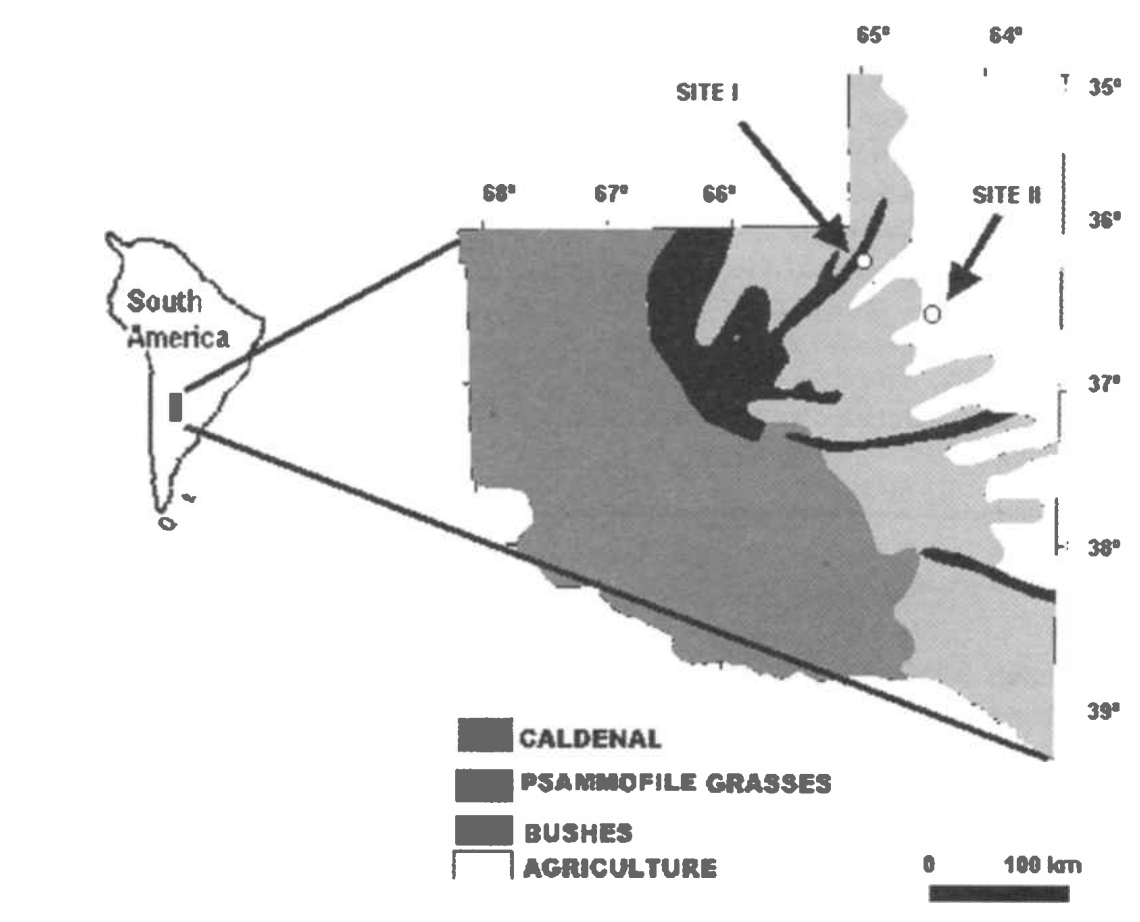

Fig. 1. Physiographic units of the La Pampa Province (INTA et al. 1980) and location of the study sites.

sites the woody strata is dominated by Caldén (Prosopis caldenia, Burkhart) trees that in average were older than 200 years. The herbaceous strata was composed of non-palatable species for cattle grazing like Stipa brachychaeta Godron, Stipa tenuissima Trinius, Stipa ichu Philippi and Baccharis ulicina Hook. et Arn, and some palatable ones that included Piptochaetium napostaense (Speg.) Hackel, Stipa tenuis Philippi, Poa ligularis Ness ex Steudel. The percentage of non-palatable species was $60 \%$ in Site I and $20 \%$ in Site II.

Both sites were extensively grazed by cattle for more than 50 years. Site I was burnt 3 times as a management strategy during the last 30 years (once every 10 years). Site II was accidentally burnt once in the same period (Table 1). Roberto et al. (1994) show that the mean annual precipitation of the region is $608 \mathrm{~mm}$, with a coefficient of variation of $25.4 \%$, the annual potential evapotranspiration, calculated with the Thornthwaite method is 815 


\section{SIIE!}

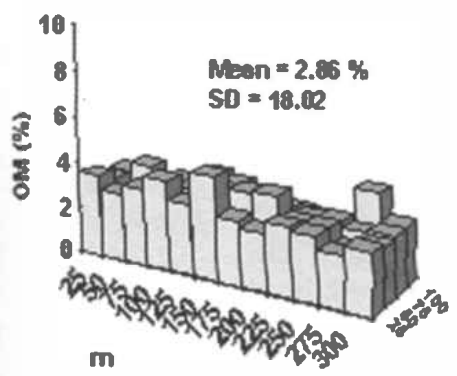

m

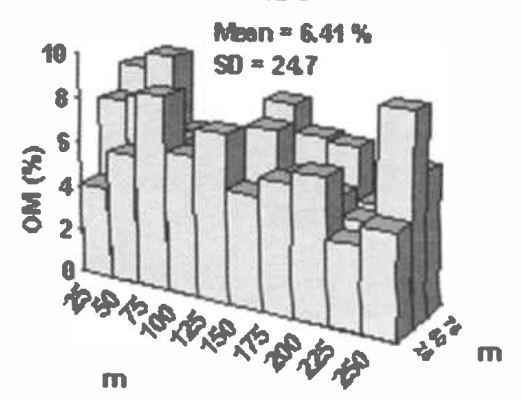

a)
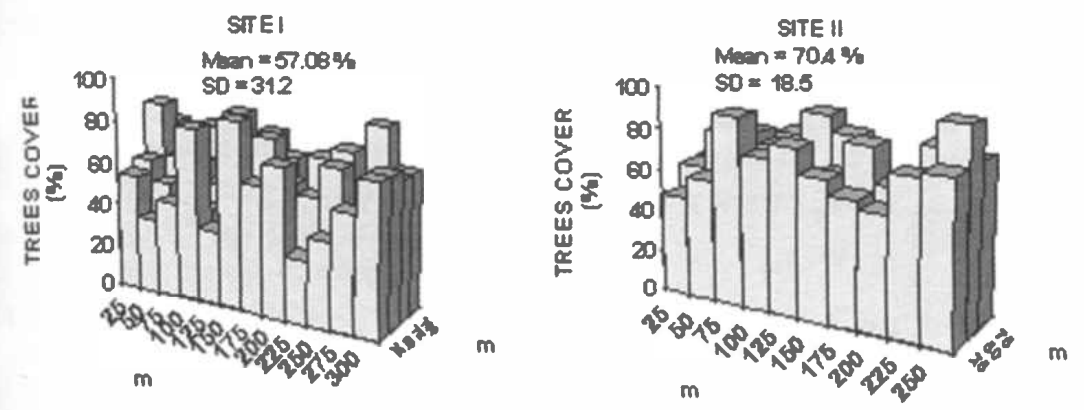

b)
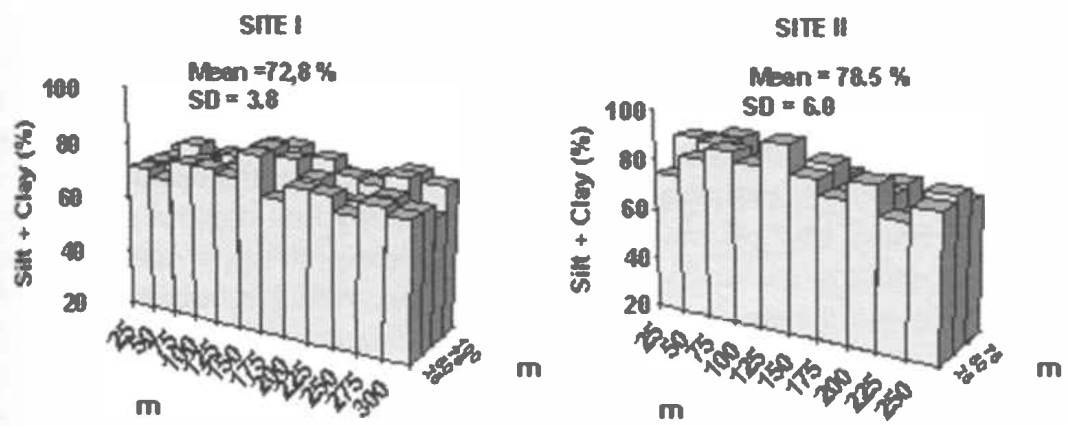

Fig. 2. a) OM, b) percent of soil cover with trees, and c) silt + clay of soils of 2 sites of the Caldenal ecosystem.

$\mathrm{mm}$, and the annual water deficit reaches $207 \mathrm{~mm}$. Precipitation occurs mostly during spring and summer $(70 \%)$.

The landscape is flat at both sites, the parent material of the soils is composed of late pleistocenic and holocenic eolian sediments (loess), and the soils at both sites were classified as Entic Haplustolls (INTA et al. 1980).

Transects were laid out at both Sites to gain an estimate of statistical variability. A $100 \mathrm{~m} \times 300 \mathrm{~m}$ sampling field was selected at Site I and a $250 \mathrm{~m} \times 75 \mathrm{~m}$ at Site II. Both sampled areas were divided into a $25 \mathrm{~m} \times 25 \mathrm{~m}$ grid, delimiting 48 and 30 , $625 \mathrm{~m}^{2}$ plots in Site I and Site II, respectively.

Soil samples were taken from the geometrical center of each plot up to $20 \mathrm{~cm}$ depth. Samples were air dried, sieved through $2 \mathrm{~mm}$, and organic matter content (OM) was determined for each sample by the Walkley and Black method (Schlichting et al. 1995). Clay and silt contents were determined by the hydrometer method (Schlichting et al. 1995) The water holding capacity of the soil was estimated by means of the centrifuge method (Schlichting et al. 1995).

Soil temperatures were measured at Site I between August 1993 and August 1995, from 2 positions: under and outside trees canopy, with an automatic Omnidata meteorological station at $1 \mathrm{~cm}$ depth. Soil water contents were monthly determined in all plots of both Sites from the first 20 soil $\mathrm{cm}$ using the gravimetric method (Schlichting et al. 1995).

Results were statistically analyzed by simple and multiple regression analysis, and means were compared by the Student $t$ test (SAS Institute Inc. 1997). Monthly soil water contents were analyzed as a function of time using a mixed model, with site, position and day as fixed effects and plots within each site as random effects. This analysis was carried out with the PROC MIXED of SAS (Littell et al.
1996). Likelihood ratio tests (LRT) were used to select among error structures (compound simmetry, autoregressive, unstructured or heterogeneous variance) compared with the null model. F-values were used for comparisons among sites and positions. Positions within sites were tested using the option SLICE of the LSMEANS statement (Singer 1998).

\section{Results and Discussion}

The effect of soil coverage and silt + clay on organic matter

The spatial variability of organic matter $(\mathrm{OM})$ contents, tree coverage and silt + clay contents of both sites are shown in Figure 2. In Site I OM contents averaged $2.86 \%$, while in Site II it averaged $6.41 \%$. Tree coverage was $57.1 \%$ in Site $I$, and $70.4 \%$ in Site II. The silt + clay content was $72.8 \%$ in Site 1 , and $78.5 \%$ in Site II. A Student t-test for comparison of means $(P<0.05)$ showed that average tree coverage and silt + clay contents were statistically lower at Site I than at Site II. Tree coverage affects soil temperature and moisture because low interception of solar radiation by the low density canopies tend to be warmer. Evaporation increases and soil water content decreases with increase solar radiation reaching the ground. Tree coverage can create a microclimatic condition which can potentially affect $\mathrm{OM}$ pools in semiarid environments.

Regression analysis was conducted to assess the influence of silt + clay and tree coverage on OM contents. The results (Fig. 3a) show that OM was significantly correlated with the percent tree cover at Site 1, but not at Site II. Conversely, a significant positive relationship between $\mathrm{OM}$ and silt + clay was observed at Site II but not at Site I (Fig. 3 b).

Correlation between tree coverage and OM may become significant when the amount of organic matter, and its spatial variability, was reduced down by the systematic occurrences from disturbing factors such as burning and grazing. Probably, there is a threshold of tree density under which $\mathrm{OM}$ and coverage are positively correlated, and over which such correlation disappears. The greater coverage by trees in Site II has probably reached a saturation point beyond which $\mathrm{OM}$ is not anymore sensitive to tree cover variability. In such case, another driving factor emerges to explain portions of residual variability. Thus, the larger $\mathrm{OM}$ content of Site II could be related to its finer soil texture (silt + clay content). This 


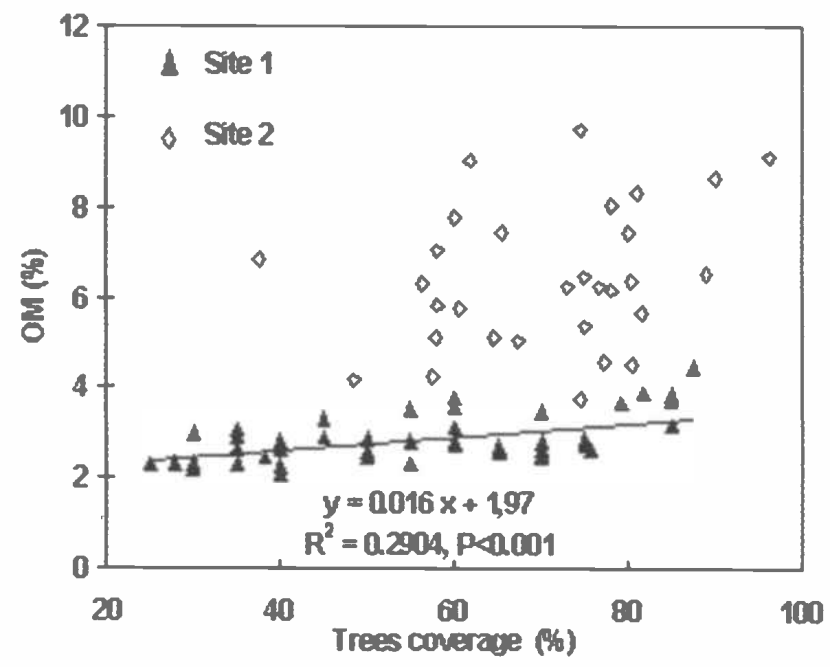

a)

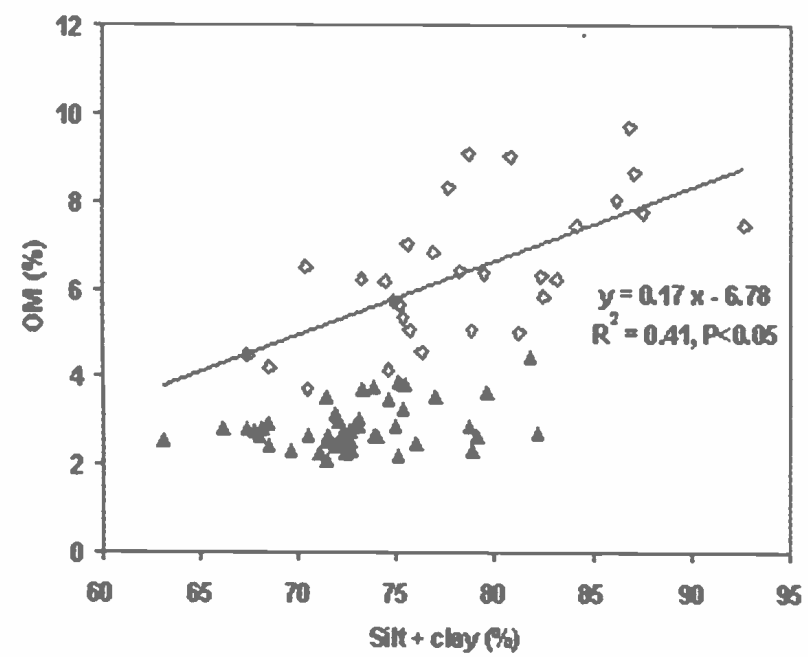

b)

Fig. 3. Soil OM contents as related to a) tree coverage trees, and b) silt + clay at 2 sites of the Caldenal ecosystem.

interpretation is in line with the results of Buschiazzo et al. (1991, 2001) finding positive relationships between $\mathrm{OM}$ accumulation and silt + clay contents in the semiarid Pampas.

Given that OM was positively correlated with the percentage of tree coverage and silt + clay content, a multiple correlation analysis of all samples from Sites I and II was performed. The results [OM $=-16.64$ +0.70 (silt + clay) +0.04 (tree coverage), $\left.\mathrm{n}=78, \mathrm{R}^{2}=0.55, \mathrm{P}<0.001\right]$ showed that both factors, in combination, have a highly significant explanatory power. Although both independent factors differed in their relative weight, this analysis indicates that both silt + clay and tree coverage favor $\mathrm{OM}$ accumulation in the ecosystem studied. These results indicate that factors other than soil texture and tree coverage explain the remaining $45 \%$ of OM variations. Burning and cattle grazing may be these additional factors.

The OM content in each Site is in agreement with previous cattle grazing intensity but not with previous fire occurrence. Site I, with lower OM contents, was more intensively grazed and more intensively burned than Site II. This agrees with the fact that higher grazing intensity can lead to lower biomass deposition into the soil decreasing thereby, OM accumulation (Facelli et al. 1988, Llorens and Frank 1999), but not with the occurrence of more frequent controlled fires in Site I. Iglesias et al. (1990) found that even accidental fires with higher temperatures than controlled fires, increased $\mathrm{OM}$ in the Caldenal ecosystem due to the incomplete combustion of plant residues and their incorporation into the soil.

The relative weight of antropic factors such as burning and grazing on OM variations cannot be clarified from this study, but it was observed that their impact on OM content was lower than that of natural factors like soil texture and tree coverage.

\section{Ecophysiological issues}

An analysis of soil temperatures of Site I (Fig. 4) shows that minimum tempera. tures were higher, and temperature amplitude was lower under the canopy than outside the canopy. Summer maximum temperature at $1 \mathrm{~cm}$ depth reached $65^{\circ} \mathrm{C}$ outside the canopy, but did not exceed $35^{\circ} \mathrm{C}$ under the canopy. In Winter, minimum temperatures varied between $2^{\circ} \mathrm{C}$ and $8^{\circ}$ $\mathrm{C}$ outside the canopy, and between $2^{\circ} \mathrm{C}$ to $5^{\circ} \mathrm{C}$ under the canopy. Thus the greater effect of tree coverage on soil temperature occurs mostly during the summer months.

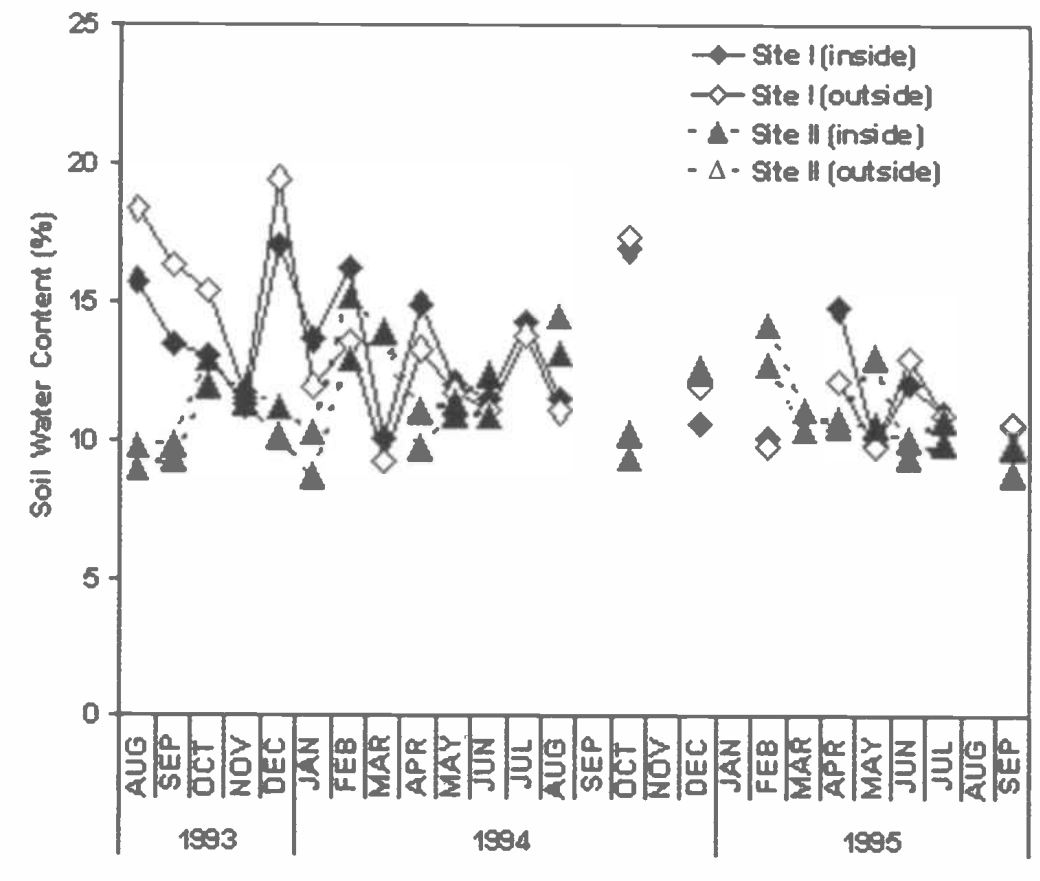

Fig. 4. Soil temperature at $1 \mathrm{~cm}$ depth, inside and outside trees canopy at Site I from August 1993 to September 1995. 
Table 2. Test of fixed effects for soil water contents.

\begin{tabular}{lcccc}
\hline \hline Source & NDF & DDF & Type III F & Pr $>$ F \\
Position (inside, outside) & 1 & 252 & 0.70 & 0.4025 \\
Site & 1 & 252 & 108.74 & 0.0001 \\
Site x Position & 1 & 252 & 2.11 & 0.1472 \\
Site x Position (inside) & 1 & 252 & 39.24 & 0.0001 \\
Site x Position (outside) & 1 & 252 & 72.49 & 0.0001 \\
Month & 20 & 252 & 25.70 & 0.0001 \\
Position x Month & 20 & 252 & 3.70 & 0.0001 \\
Site x Month & 20 & 252 & 31.45 & 0.0001 \\
Site x Position x Month & 20 & 252 & 1.88 & 0.0145 \\
\hline
\end{tabular}

$\mathrm{NDF}=$ numerator degrees of freedom, $\mathrm{DDF}=$ denominator degrees of freedom, $\mathrm{Pr}=$ probability,

The monthly soil water content in the first $20 \mathrm{~cm}$ soil layer during the period August 1993-August 1995 at both sites are presented in Figure 5. The statistical analysis (Table 2) indicated that the average soil water contents were significantly higher in Site II (13.5\%) than in Site I $(11.3 \%)$, and that such differences oecurred for most of measurement dates. Nevertheless no differences with respect to the location (inside or outside the enopy) was recorded at both sites for any measurement period. These results tend to confirm that differences in soil texture mplain differences in the water contents, as the finer textural soil composition of Site II determined its higher soil water retention than at Site I

These results suggest that in less disturbed woodland sites, OM accumulation depends on edapho-climatic conditions, which are determined by the soil texture, rather than on tree coverage. It was demonstrated that soil texture determines

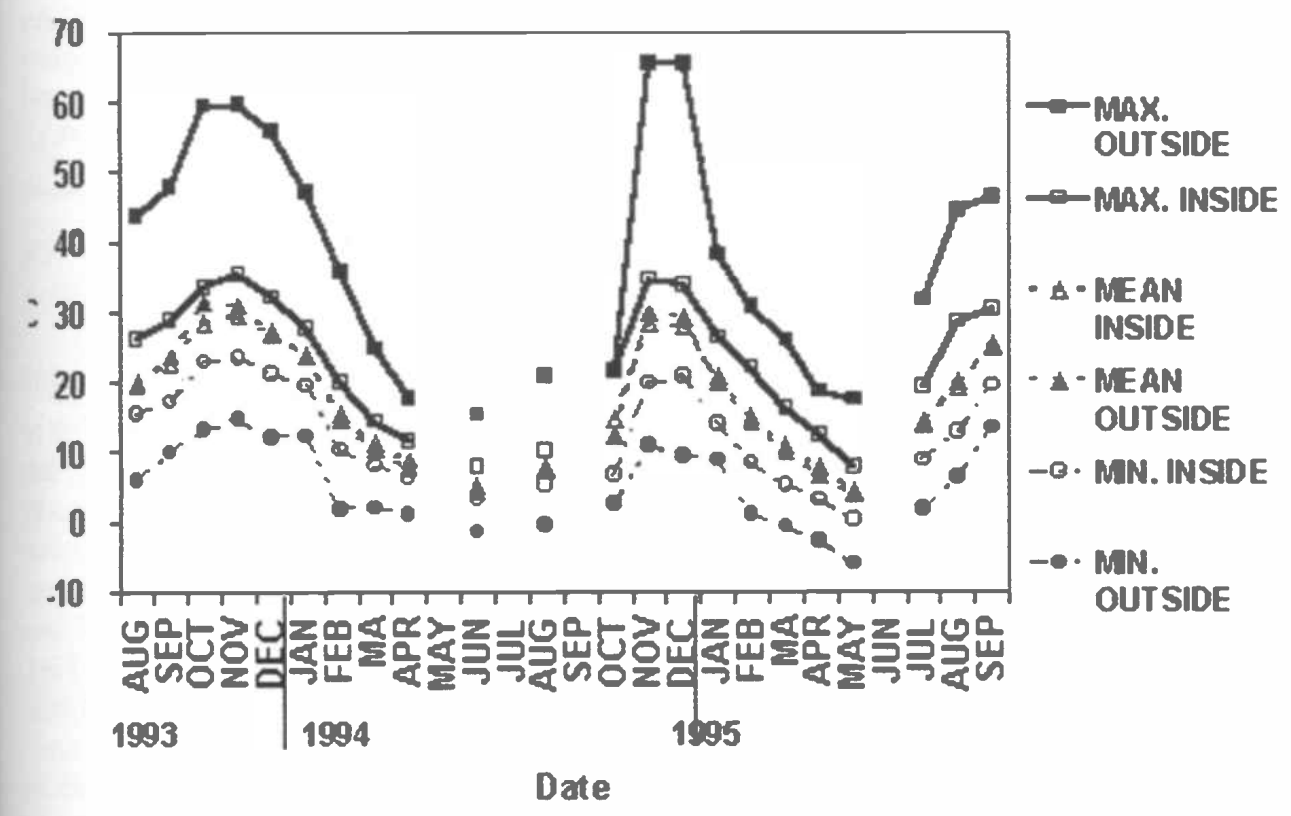

Fig. 5. Soil water contents at $20 \mathrm{~cm}$ depth, inside and outside trees canopy at both studied sites from August 1993 to September 1995. the water retention capacity of soils in the semiarid Pampas of Argentina (Quiroga and Buschiazzo 1988), and this in turn facilitates OM accumulation in soils (Buschiazzo 2002).

\section{Conclusions}

It can be concluded that (a) OM depends more on silt + clay content when tree coverage is dense and uniform, and (b) OM depends more on tree coverage when such coverage is sparse and heterogeneous. The influence of canopy density on OM distribution could be explained by its effect on temperature regime. The influence of soil texture on OM could be attributed to its effect on the water retention capacity of soils. Forest clearing can increase the maximum temperature and the temperature amplitude of soils, while erosion in cleared areas can affect the texture, and consequently, the water retention capacity

of soils. The potential deterioration of both temperature and soil water regimes, in turn can diminish the capacity of the soil to accumulate $\mathrm{OM}$.

\section{Literature Cited}

Alvarez, R. and R.S. Lavado. 1998. Climate, organic matter and clay content relationships in the Pampa and Chaco soils, Argentina. Geoderma 83:127-141.

Burke, I.C., C.M. Yonker, W.J. Parton, C.V. Cole, K. Flach, and D.S. Schimel. 1989. Texture, climate, and cultivation effects on soil organic matter content in U. S. Grassland soils. Soil Sci. Soc. Amer. J. 53:800-805.

Buschiazzo, D.E. 2002. Management systems in southern South America. In: G.A. Peterson, P.W. Unger, W.A. Payne (Eds.) Dryland Agriculture, 2nd Ed., Monograph 23. ASA/CSSA/SSSA, Madison, Wisco. (In press).

Buschiazzo, D.E., A.R. Quiroga, K., and Stahr. 1991. Patterns of organic matter distribution in soils of the semiarid Argentinean Pampas. Z. Pflanzenernähr. 154: 437-441.

Buschiazzo, D. E., G.G. Hevia, E.N. Hepper, A. Urioste, A. Bono, and F. Babinec. 2001. Organic $\mathrm{C}, \mathrm{N}$, and $\mathrm{P}$ in size fractions of virgin and cultivated soils of the semiarid Pampa of Argentina. J. Arid Env. 48:501-508.

Díaz Zorita, M., D.E. Buschiazzo, and N. Peinemann. 1999. Soil organic matter and wheat productivity in the semiarid Argentinian Pampas. Agron. J. 91:276-279.

Facelli J.M., C.M. Montero, and R.J.C. Leon. 1988. Effects of different disturbance regimes on seminatural grasslands from the subhumid pampa. Flora 180:241-249

Gregorich, E.G., M.R. Carter, D.A. Angers, C.M. Monreal, and B.H. Ellert. 1994. Towards a minimum data set to assess soil organic matter quality in agricultural soils. Can. J. Soil Sci. 74:367-385.

Iglesias D., T.E. Rucci, E.O. Frank, E. Llorens, D. E. Buschiazzo, R. Di Giuseppe, M. Obieta, and O. Salvadori. 1990. Modificaciones producidas por incendios naturales y programados sobre el estrato leñoso y herbáceo de la zona central de la Pcia. de La Pampa. Rev. Fac. Agron. UNLPam. No 5: 117-126.

INTA; Gob. La Pampa; UNLPam. 1980. Inventario integrado de los recursos naturales de la Provincia de La Pampa. INTA Buenos Aires.

Lal, R. and B. Stewart. 1990. Soil Degradation. Adv. Soil Sci. 11. 345 pp

Littell, R.C., Milliken, G.A., W.W. Stroup, and R.D. Wolfinger. 1996. SAS System for Linear Models. SAS Institute, Inc. Cary, N.C. $633 \mathrm{pp}$.

Llorens, E. and E.O. Frank. 1999. Aspectos ecológicos del estrato herbáceo del Caldenal y estrategias para su manejo. INTA, Ministerio de la Producción Pcia. La PampaCREA. Miscellaneous Publication. 
López Cadenas, F. 1990. El papel del bosque en la conservación del agua y del suelo. Ecología 1:141-155.

Mazzarino, M.J., L. Oliva, A. Nuñez, and G. Nuñez. 1991. Nitrogen mineralization and soil fertility in the dry Chaco ecosystems (Argentina). Soil Sci. Soc. Amer. J. 55:515-522.

Mordelet P. and J.C. Menaut. 1995. Influence of trees on above-ground production dynamics of grasses in a humid savanna. J. Veg. Sci. 42:223-228

Powers, R.F. 1990. Nitrogen mineralization along and altitudinal gradient: interactions of soil temperature, moisture, and substrate quality. Forest Ecol. Man. 30:19-29
Quiroga, A.R. and D.E. Buschiazzo, 1988. Correlaciones entre parámetros hídricos, densidad aparente y contenidos de materia orgánica con granulometría en suelos de la Región Semiárida Pampeana Central. Actas XII Congreso Argentino de la Ciencia del Suelo, Corrientes.

Quiroga, A.R., D. E Buschiazzo, and N. Peinemann. 1999 Soil compaction is related to management practices in the semi-arid Argentine pampas. Soil and Tillage Research $5221-28$.

Rasmussen, P.E. and H.P. Collins. 1991. Long-term impacts of tillage fertilizer, and crop residue on soil organic matter in temperate semiarid regions. Adv. Agron.. $45: 93-134$
Roberto, Z., G.A. Casagrande, and E. Viglizzo. 1994. Lluvias en la Pampa Central, tendencias y variaciones del siglo. INTA. Centro Regional La Pampa-San Luis. Publicación N ${ }^{\circ}$ 2. Sante Rosa, La Pampa. Argentina.

SAS Institute, Inc. 1997. SAS/STAT Software: Changes and Enhancements through Release 6.12. SAS Institute, Inc. Cary, N.C. 1167 pp.

Schlichting, E., K.H. Blume, and K. Stahr. 1995. Bodenkundliches Praktikum. Parey, Hamburg-Berlin.

Singer, J.D. 1998. Using SAS PROC MIXED to fit multilevel models, hierarchical models, and individual growth models. J. Educ. Behavioural Stat. 24:323-355.

Tisdale, J.M. and J.M. Oades. 1982. Organic matter and water stable aggregates in soils. J. Soil Sci. 33:141-163.

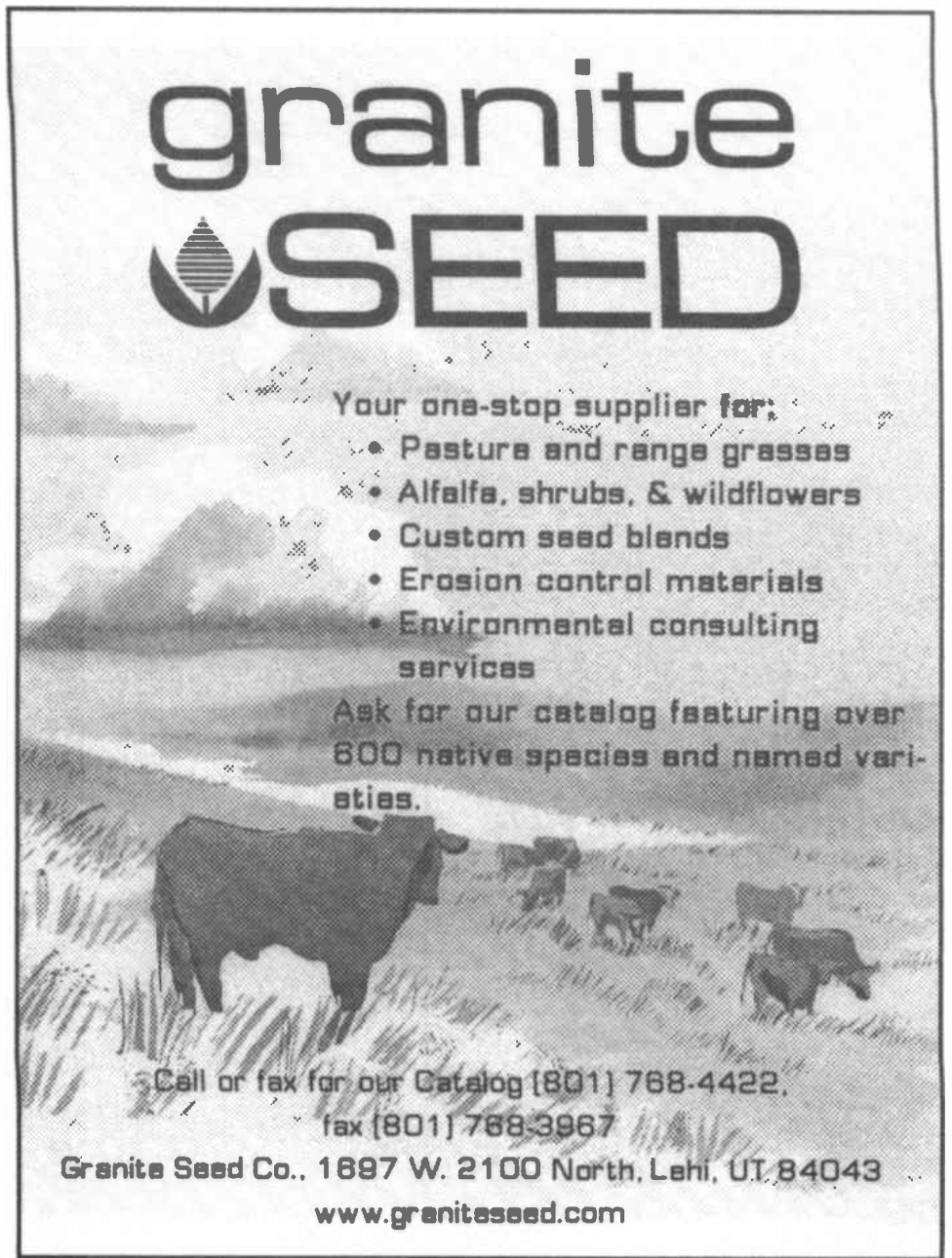

